\title{
A CLINICO-PATHOLOGICAL STUDY OF FISTULA-IN-ANO
}

\author{
Hemant B. Janugade1, Neville Hoshedar Tata², Shaikh Mohammad Ashar ${ }^{3}$, Deepali H. Janugade ${ }^{4}$, Parag Kamboj5
}

${ }_{1}^{1}$ Professor, Department of General Surgery, Krishna Institute of Medical Sciences University, Karad, Maharashtra. ${ }^{2}$ Resident, Department of General Surgery, Krishna Institute of Medical Sciences University, Karad, Maharashtra. ${ }^{3}$ Resident, Department of General Surgery, Krishna Institute of Medical Sciences University, Karad, Maharashtra. ${ }^{4}$ Assistant Professor, Department of Obstetrics and Gynaecology, Krishna Institute of Medical Sciences University, Karad, Maharashtra. ${ }^{5}$ Resident, Department of General Surgery, Krishna Institute of Medical Sciences University, Karad, Maharashtra.

\section{ABSTRACT}

\section{BACKGROUND}

Fistula-In-Ano has been one of the oldest described conditions inflicting man throughout history. It is the commonest cause for a persistent perianal discharge and discomfort. This study deals with its aetiology, pathology and the different modes of treatment and their efficacy in detail.

\section{MATERIALS AND METHODS}

For this study fifty patients were selected who were diagnosed as fistula-in-ano, admitted in Krishna Hospital and Medical Research Centre, Karad, during the period of December 2012 to May 2014. Every patient in the study underwent definitive treatment.

\section{RESULTS}

Data related to the objectives of the study were collected. Majority of patients belonged to the age group of 31-60 years, which accounts for $26(52 \%)$ of patients. Male:Female ratio is 7.3:1. Most of the fistulas are low anal $42(84 \%)$ and $22(44 \%)$ of patients developed fistula in a previously burst opened or surgically drained perianal abscess. About $33(66 \%)$ of external openings are posterior to the anal axis, of which $26(52 \%)$ followed the Goodsall's rule. Fistulectomy is commonly performed, i.e. in about 46 (92\%) of cases and the operated wound has healed in a range of 2 weeks to 4 weeks with a mean duration of 3 weeks. The postoperative complications were very minimal; there was recurrence of fistula in 1 case (2\%) after 4 weeks and it was excised again.

\section{CONCLUSION}

We concluded from the study that the spontaneously ruptured or inadequately drained pyogenic abscess is the most common aetiological factor for fistula-in-ano. Operative morbidity is usually low. There is a male predisposition for the disease and the fistulectomy remains the commonest procedure in our study series. Even with advent of newer techniques, probably to remove the diseased part at one stage operation. The post-operative complications are usually mild in nature and are minimal.

\section{KEYWORDS}

Fistula-In-Ano, Fistulectomy, Fistulotomy, Seton Placement, Perianal Abscess.

HOW TO CITE THIS ARTICLE: Janugade HB, Tata NH, Ashar SM, et al. A clinico-pathological study of fistula-in-ano. J. Evolution Med. Dent. Sci. 2016;5(86):6395-6398, DOI: 10.14260/Jemds/2016/1446

\section{BACKGROUND}

Fistula-In-Ano has been one of the oldest described conditions inflicting man throughout history. Its prevalence has been estimated to be 8.6 to $10 / 100,000$ of the population per year with a male-to-female ratio of 1.8:1.[1] Sushrutha described the condition and advocated the use of medicated setons for its treatment. Later on Hippocrates described the fistula-in-ano in about 430 B.C. suggesting that the disease was caused by "contusions and tubercles occasioned by rowing or riding on horseback." [2]

Fistula-in-ano is an abnormal communication between the anal canal or rectum and the perianal skin. The most common cause for the condition is an anorectal abscess, which ruptured spontaneously or was surgically drained. [3] Such abscesses are

Financial or Other, Competing Interest: None.

Submission 21-09-2016, Peer Review 13-10-2016,

Acceptance 21-10-2016, Published 27-10-2016.

Corresponding Author:

Dr. Neville Hoshedar Tata,

A-1, Krishna Hospital Campus,

Karad, Maharashtra, India.

E-mail: nhtata@gmail.com

DOI: $10.14260 /$ jemds/2016/1446 mostly due to infection of an anal or perianal gland.[4] Fistulae have also been reported following trauma or probing of an abscess.[5] tuberculosis, ulcerative colitis, Crohn's disease, Lymphogranuloma venereum and actinomycosis.[6] Colloid carcinoma of the rectum can also manifest itself through an anal fistula.[7]

\section{According to Park ${ }^{[8]}$ the Anal Fistula can be Classified into the Following Types \\ 1. Intersphincteric $-70 \%$. \\ 2. Transsphincteric $-25 \%$. \\ 3. Suprasphincteric $-5 \%$. \\ 4. Extrasphincteric $-1 \%$.}

The presenting complaints are intermittent or constant drainage or discharge with a history of previous pain, swelling and recurrent abscess that ruptured spontaneously or was surgically drained. There may be a pink or red opening exuding pus or it may have healed. In Crohn's disease or tuberculosis, the margins may be violaceous and the discharge watery.[9]

Physical examination remains the mainstay of its diagnosis by observation of the entire perineum, looking for an external 
opening that appears as an open sinus or elevation of granulation tissue. Discharge from an external opening may be apparent or expressible upon digital rectal examination. Digital rectal examination may reveal a fibrous tract or cord beneath the skin; it also helps to delineate any further acute inflammation that is not yet drained. Lateral or posterior induration suggests deep posterior anal or ischiorectal extraction. ${ }^{[4]}$ Proctoscopy is usually required to identify the internal opening.

Passing of probe can be attempted through the external opening and will usually reveal the course more readily. The probe should never be forced, merely gently manoeuvred for risk of causing false passages.

Commonly done investigations in fistula-in-ano are sigmoidoscopy, colonoscopy, fistulography, endoanal/endorectal ultrasound, Magnetic Resonance Imaging (MRI), Computerised Tomography Scan (CT scan) and a barium enema/small bowel series and fistuloscopy.[10]

The main object of surgical treatment is to eradicate it without disturbing the anal sphincter and affecting the continence. The three basic surgical techniques for the treatment of anorectal fistulae are fistulotomy, use of a seton and endorectal advancement flaps.[11] Fistulectomy is recommended when it is necessary to provide histologic material for analysis.[12]

Fistula-in-ano, one of common perianal disorder and there is scarcity of studies on its natural history, incidence, aetiopathogenesis, clinical features, investigations and treatment, especially in this part of the country. Hence, a prospective study on fistula-in-ano was conducted.

\section{Methodology}

A prospective study was conducted at the Department of Surgery, Krishna Hospital and Medical Research Centre in the Krishna Institute of Medical Sciences University, Karad, during the period of December 2012 to May 2014.

A number of 50 patients were selected who were admitted at the Krishna Hospital and Medical Research Centre, Karad, with a diagnosis of fistula-in-ano during the period of the study. Patients underwent definitive treatment. Data related to the objectives of the study were collected.

\section{Inclusion Criteria}

- The patients who are clinically diagnosed as fistula-in-ano in all ages and both sex who are subjected to relevant investigation and undergo surgery were to be included.

\section{Exclusion Criteria}

- All fistulas due to perineal injuries.

- All congenital fistulas.

- Cases unfit and refused for surgery.

The diagnosis of the fistula-in-ano mainly depends on clinical examination. The selected patients are subjected to pathological, biochemical and radiological investigations. Data related to preoperative and intra-operative interventions along with postoperative outcome was collected for patients who were treated with either fistulectomy, fistulotomy or seton placement.

\section{RESULTS}

In our study of 50 patients, the age of patients varies from 9 years to 80 years. Maximum number of patients were in the age group 31-60 years, i.e. 26 patients (52\%). There was 1 patient $(2 \%)$ in the age group of $\leq 10$ years, 19 (38\%) in the age between 11-30 years and 4 patients in the age above 60 years as shown in Table 1.

\begin{tabular}{|c|c|c|}
\hline Age in Years & No. of Patients & Percentage \\
\hline 10 & 1 & 2 \\
\hline $11-30$ & 19 & 38 \\
\hline $31-60$ & 26 & 52 \\
\hline$>60$ & 4 & 8 \\
\hline Total & $\mathbf{5 0}$ & $\mathbf{1 0 0}$ \\
\hline \multicolumn{3}{|c|}{ Table 1. Age Distribution } \\
\hline
\end{tabular}

In our study of 50 patients there were 44 (88\%) male patients, $6(12 \%)$ female patients indicating that the disease is more common in male with a ratio of male-to-female is $7.3: 1$ as shown in Table 2 .

\begin{tabular}{|c|c|c|}
\hline Sex & No. of Patients & Percentage \\
\hline Male & 44 & 88 \\
\hline Female & 6 & 12 \\
\hline Total & $\mathbf{5 0}$ & $\mathbf{1 0 0}$ \\
\hline \multicolumn{2}{|c|}{ Table 2. Sex Wise Distribution } \\
\hline
\end{tabular}

In our study most of the patients were manual labourers $40(80 \%)$, while $6(12 \%)$ were businessmen and $4(8 \%)$ were students as shown in Table 3.

\begin{tabular}{|c|c|c|}
\hline Occupation & No. of Cases & Percentage \\
\hline Manual labour & 40 & 80 \\
\hline Businessmen & 6 & 12 \\
\hline Student & 4 & 8 \\
\hline \multicolumn{2}{|r|}{ Table 3. Occupational Incidence } \\
\hline
\end{tabular}

In the present study, the commonest symptoms is discharge in all patients with pruritis in $34(68 \%)$ patients and pain in $26(52 \%)$ patients. The commonest sign is presence of external opening in all cases, internal opening in 42 (84\%) of patients and swelling in 22 (44\%) cases as depicted in Table 4.

\begin{tabular}{|c|c|c|}
\hline Symptoms and Signs & No. of Patients & Percentage \\
\hline Pain & 26 & 52 \\
\hline Discharge & 50 & 100 \\
\hline Swelling & 22 & 44 \\
\hline Pruritis & 34 & 68 \\
\hline External opening & 50 & 100 \\
\hline Internal opening & 42 & 84 \\
\hline Bleeding per rectum & 4 & 8 \\
\hline \multicolumn{2}{|c|}{ Table 4. Signs and Symptoms } \\
\hline
\end{tabular}

The commonest type of fistula was low anal as shown in Table 5.

\begin{tabular}{|c|c|c|}
\hline Type & No. of Patients & Percentage \\
\hline Subcutaneous & 6 & 12 \\
\hline Low anal & 42 & 84 \\
\hline High anal & 2 & 4 \\
\hline Submucous & - & - \\
\hline Pelvirectal & - & - \\
\hline \multicolumn{2}{|c|}{ Table 5. Distribution on the Basis of Type } \\
\hline
\end{tabular}

Out of the 50 cases studied 33 (66\%) cases had posterior openings, 12 (24\%) cases had anterior openings and 5 (10\%) cases had lateral external openings as depicted in Table 6. 


\begin{tabular}{|c|c|c|}
\hline Relation to Anal Axis & No. of Patients & Percentage \\
\hline Anterior & 12 & 24 \\
\hline Posterior & 33 & 66 \\
\hline Lateral & 5 & 10 \\
\hline Table 6. Distribution on the Basis of Location \\
\hline
\end{tabular}

Many associated conditions along with fistulae-in-ano were noted, commonest condition was anorectal abscess (burst opened or surgically drained) which was found in 22 (44\%) cases, fissure in $2(4 \%)$ cases, pulmonary TB in $2(4 \%)$ cases, haemorrhoids in $4(8 \%)$ cases and BPH in $3(6 \%)$ cases as shown in Table 7.

\begin{tabular}{|c|c|c|}
\hline Type & No. of Patients & Percentage \\
\hline Fissure & 2 & 4 \\
\hline Pulmonary TB & 2 & 4 \\
\hline Haemorrhoids & 4 & 8 \\
\hline BPH & 3 & 6 \\
\hline Anorectal abscess & 22 & 44 \\
\hline \multicolumn{2}{|c|}{ Table 7. Associated Conditions } \\
\hline
\end{tabular}

Majority of the cases were treated with a fistulectomy 46 (92\%), while fistulotomy was done in 2 (4\%) of the cases and seton placement was done in $2(4 \%)$ of the cases as shown in Table 8.

\begin{tabular}{|c|c|c|}
\hline Type of Operation & No. of Patients & Percentage \\
\hline Fistulectomy & 46 & 92 \\
\hline Fistulotomy & 2 & 4 \\
\hline Seton placement & 2 & 4 \\
\hline Mucosal advanced flap & - & - \\
\hline Fibrin glue injection & - & - \\
\hline Colostomy & - & - \\
\hline
\end{tabular}

Most of the cases healed within 2-4 weeks with a mean time of 3 weeks as shown in Table 9.

\begin{tabular}{|c|c|c|}
\hline Time & No. of Patients & Percentage \\
\hline 1 week & 1 & 2 \\
\hline 2 weeks & 10 & 20 \\
\hline 3 weeks & 12 & 24 \\
\hline 4 weeks & 17 & 34 \\
\hline 5 weeks & 5 & 10 \\
\hline 6 weeks & 1 & 2 \\
\hline 7 weeks & 1 & 2 \\
\hline 8 weeks & 1 & 2 \\
\hline 10 weeks & 2 & 4 \\
\hline Total & 50 & 100 \\
\hline
\end{tabular}

Followup, most of the patients came for followup only once or twice in the three months to six months post-operative period. There was recurrence in one case after 4 weeks and it was excised.

Out of 50 cases, fistulectomy was done in 46 cases and the excised specimen was sent for histopathological examination. 44 cases were diagnosed as due to non-specific inflammation and 2 cases were of tubercular aetiology Table 10.

\begin{tabular}{|c|c|}
\hline Histopathology Report & No. of Patients \\
\hline Nonspecific inflammation & 44 \\
\hline \multicolumn{2}{|c|}{ Tuberculosis } \\
\hline \multicolumn{2}{|c|}{ Table 10. Distribution on the Basis of } \\
Histopathological Analysis \\
\hline
\end{tabular}

A few patients had transient incontinence for fluids and flatus for about 2 weeks which was probably due to operative oedema, pain and to some extent lack of tone of sphincter musculature; other complications were post-operative wound infection, retention of urine and post-operative headaches as shown in Table 11.

\begin{tabular}{|c|c|c|}
\hline Complications & $\begin{array}{c}\text { No. of } \\
\text { Patients }\end{array}$ & Percentage \\
\hline $\begin{array}{c}\text { Postoperative wound } \\
\text { infection }\end{array}$ & 8 & 16 \\
\hline Retention of urine & 2 & 4 \\
\hline Postoperative headache & 3 & 6 \\
\hline Recurrence & 1 & 2 \\
\hline Incontinence & - & - \\
\hline Stricture & - & - \\
\hline \multicolumn{2}{|c|}{ Table 11. Complications } \\
\hline
\end{tabular}

There was no post-operative mortality among the cases in the present study.

\section{DISCUSSION}

There is a more male dominance in reported series.[13] Kim JW et al reported the male:female of 4.6:1 in Korea.[14] Most patients with an anal fistula present in the third or fourth decade of life[15] and anal fistulas were uncommon after the age of 60 years.

In our study also there is a male predominance with a ratio of 7.3:1. Most of the patients in our study present between the 31-60 years and only 4 were in the age group of more than 60 years shows that our study almost matches with their study in male:female ratio and age incidence.

As per the study done by Marks and Ritchie[15] in a series of 793 patients, the fistulas were divided as intersphincteric (49.5\%), transsphincteric (27.7\%), suprasphincteric (6.5\%), extrasphincteric (2.9\%) and others at $13.4 \%$.

In our study, intersphincteric is $96 \%$ and suprasphincteric is $4 \%$. This disparity may be explained by the fact that our study constituted a very small study group (50 patients).

In a study done by Marks and Ritchie,[15] the site of internal opening is anterior, posterior and lateral. In our study anterior in $24 \%$, posterior in $66 \%$ and lateral in $10 \%$ almost matches with the above said study.

A patient with a fistula-in-ano often recounts a history of an abscess, drained either surgically or spontaneously.

Patients may complain of drainage, pain with defecation, bleeding.[10] Vasilevsky and Gordon[16] recorded a history of discharge, anal pain, a recurrent perianal swelling, bleeding and pruritis. Associated fissure-in-ano was recorded in their patients. Many patients also have haemorrhoids.

In our study, a history of discharge was in $100 \%$, anal pain in $52 \%$, a recurrent perianal swelling in $44 \%$, bleeding in $8 \%$ and pruritis in $68 \%$ of patients. Associated fissure-in-ano was recorded in $4 \%$ of patients and haemorrhoids in $8 \%$ of patients, almost nearer to their study.

Parks and Stitz ${ }^{[17]}$ demonstrated that hospital stay and healing times was much longer in patients treated for transsphincteric and suprasphincteric as compared with those treated for an intersphincteric fistula.

In our study also, the suprasphincteric anal fistulas took 10 weeks and intersphincteric fistulas 1 week to 5 weeks to heal matches with their study. 
True faecal incontinence is variable, ranging from nil to $26 \%$. In our study, few patients had transient incontinence for fluids and flatus for about 2 weeks matches with the most of the case reports. The morbidity is much low and the present record for more conservative methods for treating extrasphincteric fistulas is more encouraging and holds real promise for a more successful outcome for fistula surgery in the future.

\section{CONCLUSION}

This study comprises 50 patients diagnosed to have fistula-inano. Analysis of the data obtained regarding the aetiopathogenesis and the various treatment modalities employed, the following conclusions were drawn -

1. Majority of patients belonged to age group of 31-60 years, which accounts for $26(52 \%)$ patients.

2. Male:female ratio was higher, i.e. 7.3:1. The disease thus affects mainly males.

3. $80 \%$ patients were from heavy working class.

4. Among the series of cases studied, the commonest type of fistula were low anal and posterior.

5. The commonest aetiology was inadequately treated as pyogenic abscesses from non-specific cases. Two cases were of tubercular aetiology.

6. The most common presenting symptom was discharge through the external opening and the physical findings observed on examination were tenderness, induration, swelling and internal opening.

7. Digital examination per rectally and examination with a probe were satisfactory methods by which the varieties, relation to anorectal ring could be assessed.

8. Conservative treatment not advised to any patient.

9. In majority of the cases fistulectomy was done in 46 (92\%), in two cases fistulotomy with scooping of the discharge and in two cases seton placement operation was done. The wound was allowed to heal by granulation tissue. Routine toilet of the wounds was done. One case had a recurrence within 4 weeks, wherein the track was excised and wound allowed to heal by granulation tissue.

10. The immediate postoperative complication was acute retention of urine in 2 cases for which catheterisation was done.

11. The wound healed in majority of cases within 2-4 weeks.

12. The specimen after fistulectomy sent for histopathological examination in 46 cases, the report was non-specific inflammation in 44 cases and tubercular infection in 2 cases.

13. Many cases of fistula-in-ano could have been prevented by proper and adequate treatment of perianal and ano-rectal suppurations and by proper instructions to the patient about the future consequences and sequelae of suppuration.

\section{REFERENCES}

1. Deeba S, Aziz O, Sains PS, et al. Fistula-in-ano: advances in treatment. The American Journal of Surgery 2008;196(1):95-9.

2. Babu AK, Naik MB, Babu MR, et al. Seton - as a gold standard treatment for high fistula in ano. Journal of Evidence Based Medicine And Healthcare 2015;2(11): 1687-93.

3. Russel TR. Anorectum. In: Lawrence W. edr. Current surgical diagnosis and treatment. 10th edn. 1994.

4. Adams D, Kovalcik PJ. Fistula in ano. Surg Gynecol Obstet 1981;153(5):731-2.

5. Gupta PJ. Frequency fistulotomy: a better tool radio frequency fistulotomy: a better tool than the conventional techniques in anal fistula. Indian J Surg 2006;68:48-52.

6. Parks AG. Pathogenesis and treatment of fistuila-in-ano. Br Med J 1961;1(5224):463-9.

7. Panda UN. Current medical diagnosis and treatment. $3^{\text {rd }}$ edn. New Delhi: Jaypee Brothers Publishers 2002.

8. Vasilevsky CA, Gordon PH. Benign anorectal: abscess and fistula. http:// eknygos. lsmuni.lt/ springer/526/192214.pdf.

9. Yamada T. Textbook of gastroenterology. $5^{\text {th }}$ edn. UK: John Wiley \& Sons 2011; P. 3712.

10. Anal fistula / fistula in ano. https://sites.google.com/site/drsumeryadavcom /analsurgery/anal-fistula-fistula-in-ano

11. Sainio P. Fistula-in-ano in a defined population. Incidence and epidemiological aspects. Ann Chir Gynaecol 1984;73(4):219-24.

12. Kim JW, Kwon SW, Son SW, et al. Comparative review of perianal sinus \& fistula in ano. J Korean Soc Coloproctol 2000;16(1):7-11.

13. Marks CG, Ritchie JK. Anal fistulas at St Mark's Hospital. Br J Surg 1977;64(2):84-91.

14. Vasilevsky CA, Gordon PH. The incidence of recurrent abscesses or fistula-in-ano following anorectal suppuration. Dis Colon Rectum 1984;27(2):126-30.

15. Parks AG, Stitz RW. The treatment of high fistula-in-ano. Disease of the Colon and Rectum 1976;19(6):487-99.

16. Goligher JC, Duthie HL, Nixon HH. Fistula-in-ano. Chapter 7. In: Surgery of the anus, rectum and colon. $4^{\text {th }}$ edn. London: Bailliere Jindal 1980:163-97.

17. Isbister WH. Fistula in ano: a surgical audit. International Journal of Colorectal Disease 1995;10(2):94-6. 